\title{
Morvan's syndrome with anti contactin associated protein like 2 - voltage gated potassium channel antibody presenting with syndrome of inappropriate antidiuretic hormone secretion
}

\author{
Anjani Kumar Sharma, Manminder Kaur, Madhuparna Paul \\ Department of Neurology, Sawai ManSingh Medical College, Jaipur, Rajasthan, India
}

\begin{abstract}
Morvan's syndrome is a rare autoimmune disorder characterized by triad of peripheral nerve hyperexcitability, autonomic dysfunction, and central nervous system symptoms. Antibodies against contactin-associated protein-like 2 (CASPR2), a subtype of voltage-gated potassium channel (VGKC) complex, are found in a significant proportion of patients with Morvan's syndrome and are thought to play a key role in peripheral as well as central clinical manifestations. We report a patient of Morvan's syndrome with positive CASPR2-anti-VGKC antibody having syndrome of inappropriate antidiuretic hormone as a cause of persistent hyponatremia.
\end{abstract}

Key words: Anti-voltage-gated potassium channel antibodies, hyponatremia, myokymia, Morvan's syndrome, syndrome of inappropriate antidiuretic hormone

\section{Introduction}

Morvan's syndrome is a rare autoimmune disorder characterized by peripheral nerve hyperexcitability, autonomic dysfunction, and central nervous system symptoms. ${ }^{[1]}$ The syndrome of muscle twitching, dysautonomia, insomnia, and delirium was first reported by Morvan by the name of la choree fibrillare in $1890 .^{[2]}$ We report a rare case of contactin-associated protein-like 2 (CASPR2), a subtype of voltage-gated potassium channel (VGKC) complex antibody positive Morvan's syndrome, with syndrome of inappropriate antidiuretic hormone secretion (SIADH).

\section{Address for correspondence:}

Dr. Manminder Kaur, Department of Neurology,

Sawai ManSingh Medical College,

Jaipur, Rajasthan, India.

E-mail:dr.manminder@gmail.com

\begin{tabular}{|l|l|}
\hline \multicolumn{2}{|c|}{ Access this article online } \\
\hline Quick Response Code: & Website: \\
\hline & www.ruralneuropractice.com \\
\cline { 2 - 3 } & \\
\hline & \\
&
\end{tabular}

\section{Case Report}

A 45-year-old male presented with 4-month duration of nonradiating mild back pain, followed a month later by burning sensation in palms and soles with nocturnal exacerbations. He developed abnormal twitching of muscles in both upper and lower limbs. He became aggressive, over-talkative, and insomniac over 15 days before presentation. He had significant weight loss during the period.

On examination, he was anxious and restless, having resting tachycardia and excessive sweating. His higher mental function and cranial nerves examinations were normal. He had continuous undulating twitching in both upper and lower limbs and back muscles. His knee and ankle jerks were sluggish and rest of the examination was normal.

This is an open access article distributed under the terms of the Creative Commons Attribution-NonCommercial-ShareAlike 3.0 License, which allows others to remix, tweak, and build upon the work non-commercially, as long as the author is credited and the new creations are licensed under the identical terms.

For reprints contact: reprints@medknow.com

How to cite this article: Sharma AK, Kaur M, Paul M. Morvan's syndrome with anti contactin associated protein like 2 - voltage gated potassium channel antibody presenting with syndrome of inappropriate antidiuretic hormone secretion. J Neurosci Rural Pract 2016;7:577-9. 
Hemogram, renal, liver, and thyroid functions were normal. Electromyography showed spontaneous activity including myokymic discharges [Figure 1], doublets, and triplets in both upper and lower limb muscles. Magnetic resonance imaging of the brain and lumbosacral spine was normal. The patient had positive serum anti-CASPR2 antibody, a subtype of VGKC complex detected by immunofluorescence method. His cerebrospinal fluid examination showed raised proteins $76 \mathrm{mg} / \mathrm{dl}$ (normal: 20-40 mg/dl), with normal cell count (cells: $3 / \mathrm{mm}^{3}$, all lymphocytes). Computed tomography (CT) of the chest showed no evidence of thymoma. The patient was diagnosed as Morvan's syndrome with positive anti-CASPR2 - VGKC antibody.

There was persistent low serum sodium in the range of $125-130 \mathrm{mEq} / \mathrm{L}$, for which patient was evaluated. His urinary osmolarity was raised $(216.36 \mathrm{mOsm} / \mathrm{kg}$, normal $<100 \mathrm{mOsm} / \mathrm{kg}$ ) and random urinary sodium was increased $(42 \mathrm{mmol} / \mathrm{L}$, normal $<30 \mathrm{mmol} / \mathrm{L})$. The serum osmolarity was decreased $(271.5 \mathrm{mOsm} / \mathrm{kg})$ and urinary specific gravity was 1.010. These findings showed SIADH secretion as a cause of his persistent hyponatremia. The patient was treated with intravenous immunoglobulin (IV Ig) $2 \mathrm{~g} / \mathrm{kg}$ in 5 divided doses. He was given phenytoin at dose of $100 \mathrm{mg}$ three times a day for symptomatic relief for twitching, which acts as membrane stabilizer. The patient was started on oral prednisone $(1 \mathrm{mg} / \mathrm{kg})$ and fluid restriction was advised.

He had marked improvement in muscle twitching and was able to sleep properly with immunotherapy. Electromyography done 2 weeks after the course of IV Ig showed decrease in spontaneous activity; occasional fasciculations were seen. His hyponatremia was also corrected. On follow-up, after 3 months, the patient was completely normal and electromyography showed no spontaneous activity. Oral prednisone was given

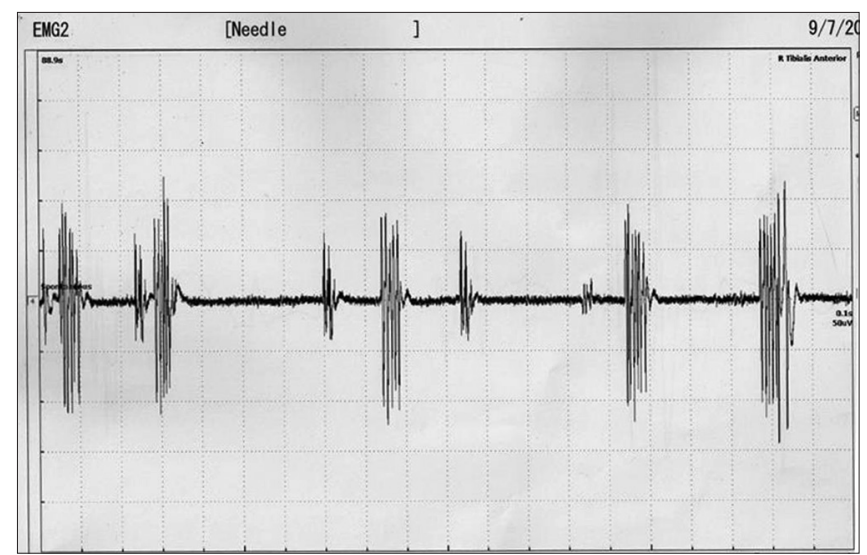

Figure 1: Spontaneous activity in right tibialis anterior showing myokymic discharges (sweep speed: $0.1 \mathrm{~ms}$ and sensitivity: $50 \mu \mathrm{V}$ )
$1 \mathrm{mg} / \mathrm{kg}$ for 3 months and later tapered gradually over next 2 months.

\section{Discussion}

Morvan's syndrome is characterized by myokymia associated with muscle pain, excessive sweating, weight loss, hallucinations, sleep disorders, and behavioral abnormality. ${ }^{[1,3]}$ This is considered as a form of neuromyotonia having prominent central features. There was considerable overlap between central and peripheral features in our patient. The basic mechanism for both presentations is same, that is anti-VGKC antibody, acts at different levels of neuraxis, both at central and peripheral level. ${ }^{[4]}$ Association of SIADH is uncommon in VGKC-CASPR2 antibodies positive cases but common in anti-leucine-rich glioma inactivated-1 (LGI-1) antibodies positive cases. ${ }^{[5]}$

VGKC-complex antibodies include both CASPR2 and LGI-1antibodies. LGI-1 antibodies are usually associated with hyponatremia, and CASPR2 antibodies are usually associated with thymomas which carry poor prognosis. CASPR2 antibodies mostly bind the neuropil, whereas antibodies to LGI-1 bound to neuronal cell bodies including the antidiuretic hormone-secreting and orexin-secreting hypothalamic neurons present in hypothalamus, raphe nucleus, and locus coeruleus. Hyponatremia is not commonly reported in Morvan's syndrome although it is present in half of the patient in LGI-1 antibodies positive limbic encephalitis. ${ }^{[5]}$

The classical electromyographic finding is the myokymic and neuromyotonic discharges. In addition, fasciculation, doublets, triplets, multiplets, and positive sharp waves are also present. Management includes antiepileptic drugs and immunotherapy which improve the clinical and electrophysiologic manifestations. ${ }^{[6]}$

This is a rare case report of Morvan's syndrome with SIADH having anti-CASPR2-VGKC antibodies that responded to immunosuppression.

\section{Financial support and sponsorship}

Nil.

\section{Conflicts of interest}

There are no conflicts of interest.

\section{References}

1. Josephs KA, Silber MH, Fealey RD, Nippoldt TB, Auger RG, Vernino S. Neurophysiologic studies in Morvan syndrome. J Clin Neurophysiol. 2004;21:440-5. 
2. Löscher WN, Wanschitz J, Reiners K, Quasthoff S. Morvan's syndrome: Clinical, laboratory, and in vitro electrophysiological studies. Muscle Nerve 2004;30:157-63.

3. Josephs KA, Silber MH, Fealey RD, Nippoldt TB, Auger RG, Vernino S. Neurophysiologic studies in Morvan syndrome. J Clin Neurophysiol 2004;21:440-5.

4. Panagariya A, Kumar H, Mathew V, Sharma B. Neuromyotonia: Clinical profile of twenty cases from northwest India. Neurol India 2006;54:382-6.

5. Irani SR, Pettingill P, Kleopa KA, Schiza N, Waters P, Mazia C, et al.

Morvan syndrome: Clinical and serological observations in 29 cases. Ann Neurol 2012;72:241-55.

6. Rana SS, Ramanathan RS, Small G, Adamovich B. Paraneoplastic Isaacs' syndrome: A case series and review of the literature. J Clin Neuromuscul Dis $2012 ; 13: 228-33$ 